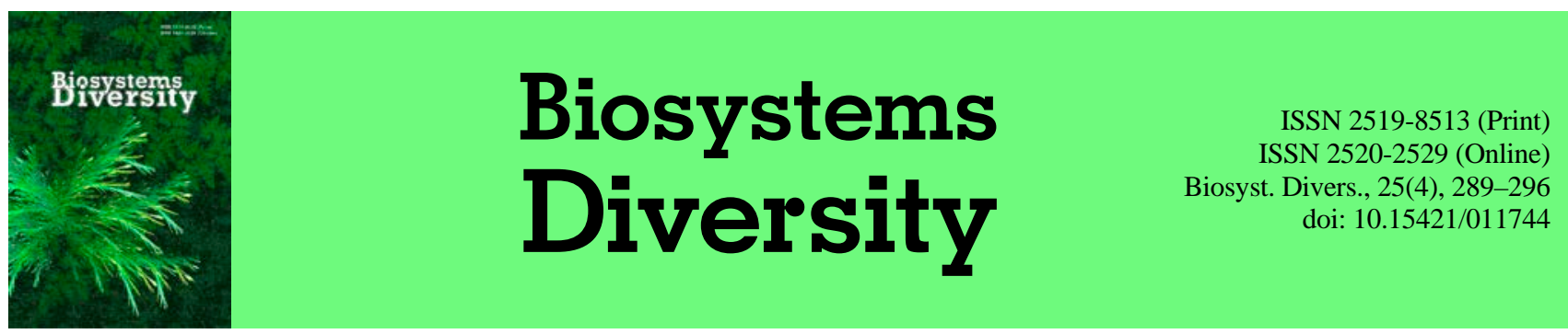

\title{
The influence of different compounds of trace elements on the biomass and synthesis of exopolysaccharides of mycelium Trametes versicolor (Polyporaceae, Polyporales)
}

\author{
G. A. Al-Maali \\ M. G. Kholodny Institute of Botany of NAS of Ukraine, Kyiv, Ukraine
}

Article info

Received 19.10.2017

Received in revised form 11.11.2017

Accepted 16.11.2017

M. G. Kholodny Institute of Botany of the National Academy of Sciences of Ukraine,

Tereshchenkivska st., 2,

Kyiv, 01601, Ukraine.

Tel.: +38-044-272-32-03

E-mail:

galeb.almaali@gmail.com

\begin{abstract}
Al-Maali, G. A. (2017). The influence of different compounds of trace elements on the biomass and synthesis of exopolysaccharides of mycelium Trametes versicolor (Polyporaceae, Polyporales). Biosystems Diversity, 25(4), 289296. doi:10.15421/011744

This article presents the results of research on the influence of citrates of zinc, manganese and copper, obtained by the method of aquanotechnology, on a number of physiological indicators of a valuable medicinal mushroom Trametes versicolor 353. Previously we detected that these metal citrates stimulated the growth of mycelium more intensively than sulfates of the above-mentioned metals in equal concentrations. In the present research we investigated the influence of these metal citrates on the parameters of assimilation of carbon and nitrogen sources, metal ion accumulation and synthesis of exopolysaccharides. The degree of metals ions accumulation in the mycelium was studied by the method of optical emission spectroscopy with an inductively coupled plasma. The economic coefficient of biomass synthesis and impact of nitrogen assimilation were higher on media with the metals citrate than on the medium with the sulfates of the studied metals. Thus, the highest economic coefficient of biomass synthesis (36\%) was observed on the medium with copper citrate. Also, copper citrate (amongst the studied metals) increased the level of assimilation of the nitrogen source by up to $35 \%$, versus $18 \%$ on the control medium. Quantitative analysis of trace elements in biomass showed that the mycelium accumulated an equal amount of zinc or manganese ions on both types of media (with citrate or sulfate of these metals). However, on the medium with copper citrate, mycelium of $T$. versicolor 353 accumulated copper ions better then on a medium with copper sulfate: $82.9 \mu \mathrm{g} / \mathrm{g}$ of biomass on the medium with copper sulfate versus $162.0 \mu \mathrm{g} / \mathrm{g}$ of biomass on the medium with copper citrate. Also the results show that a significant increase of biomass (by 79\% relative to the control) on the copper citrate medium is due to a threefold reduction of the exopolysaccharides amount. This data indicates a greater biological activity of copper citrate, relative to copper sulfate. Only zinc citrate raised both the synthesis of biomass and the synthesis of exopolysaccharides by $37 \%$ and $29 \%$ respectively ( relative to the control trial).
\end{abstract}

Keywords: citrates of metals; zinc; manganese; copper; aquanotechnology; economic coefficient

\section{Вплив різних сполук мікроелементів на синтез біомаси та екзополісахаридів міцелісм Trametes versicolor (Polyporaceae, Polyporales)}

\author{
Г. А. Аль-Маалі
}

\author{
Інститут ботаніки імені М. Г. Холодного НАН України, Київ, Україна
}

\begin{abstract}
Наведено дані щодо впливу цитратів металів (цинку, мангану та купруму), отриманих методом аквананотехнології, на низку фізіологічних показників міцелію цінного лікарського гриба Trametes versicolor (L.) Lloyd. Із метою пояснення ефекту збільшення біомаси штаму T. versicolor 353 за впливу зазначених цитратів металів (порівняно із сульфатами відповідних металів) досліджували параметри засвоєння джерела карбону та нітрогену, ступінь акумуляції міцелієм іонів цих металів та їх вплив на синтез екзополісахаридів. Економічний коефіцієнт синтезу біомаси та показники асиміляції нітрогену вищі на середовищах із цитратами, ніж на середовищі із сульфатами відповідних металів. Найвищий економічний коефіціснт синтезу біомаси (36\%) спостерігали на середовищі із цитратом купруму. Відповідно цитрат купруму найбільше серед досліджених металів підвищував рівень асиміляції джерела нітрогену до $35 \%$ проти $18 \%$ на контрольному середовищі. Концентрація іонів купруму у міцелії, культивованому на середовищі із сульфатом купруму, становила 83,0 мкг/г біомаси, а на середовищі із цитратом купруму - 162,0 мкг/г біомаси. Значне зростання біомаси (на $79 \%$ відносно контролю) за дії цитрату купруму, отриманого методом аквананотехнології, відбувається за рахунок зниження синтезу екзополісахаридів утричі порівняно $з$ контролем. Кількісний аналіз іонів цинку та мангану в біомасі T. versicolor 353 не виявив суттєвої різниці між біодоступністю цитратної та сульфатної форми зазначених металів. Серед використаних у дослідженні сполук лише цитрат цинку порівняно з контролем одночасно збільшував і синтез біомаси (на $37 \%$ ), і синтез екзополісахаридів (на 29\%).
\end{abstract}

Ключові слова: цитрати металів; мідь; цинк; марганець; аквананотехнологія; економічній коефіцієнт 


\section{Вступ}

Багато видів шапинкових базидієвих грибів проявляють лікарські або функціональні властивості та різноманітну біологічну активність, пов'язані з різними клітинними компонентами та вторинними метаболітами (Elisashvili et al., 2014). Чільне місце серед лікарських базидієвих грибів посідає Trametes versicolor (L.) Lloyd, плодові тіла якого 3 давніх часів використовують у традиційній китайській медицині (Ying et al., 1987). Сучасні численні дослідження довели доцільність використання препаратів, отриманих із T. versicolor для лікування та профілактики онкологічних захворювань, запальних та інфекційних процесів тощо (Monro, 2003; Kao et al., 2013; Barros et al., 2016; Leliebre-Lara et al., 2016). Як і у випадку з іншими лікарськими базидіоміцетами, 3 профілактичною та лікувальною метою найчастіше використовують екстракти, отримані з біомаси T. versicolor. Фармакологічні властивості цих екстрактів досить добре вивчені (Mizuno, 1999; Habbs, 2012). Основні біоактивні компоненти екстрактів із біомаси T. versicolor, яким приділяють увагу в більшості досліджень, - це полісахариди (Chu et al., 2002; Cui and Chisti, 2003; Rowan et al., 2003; Arteiro et al., 2012; Barros et al., 2016). Експериментально доведено, що різні фракції полісахаридів, отриманих із міцелію або плодових тіл T. versicolor, мають багато лікарських властивостей (Habbs, 2012), серед яких особливо значні імуномоделювальна (Tsukagoshi et al., 1984; Chu et al., 2002; Standish et al., 2008), протипухлинна (Chow et al., 2003; Aoyagi et al., 2009; Torkelson et al., 2012; Wenner et al., 2013), противірусна (Hirose et al., 1987; Monma et al., 1997; Donatini, 2014), фунгіцидна (Ohmura et al., 2001; Ohmura et al., 2003) та гепатопротекторна (Yeung et al., 1994).

Органічні сполуки металів характеризуються більшою біологічною доступністю, ніж неорганічні аналоги. Перспективні з цього погляду солі карбонових кислот: цитрати металів, дозволені до використання у харчовій промисловості (Borysevych et al., 2010). Традиційні методи отримання карбоксилатів трудомісткі й енергозатратні. Отримані сполуки мають низьку хімічну чистоту. Інтенсивний розвиток нанотехнологій дав змогу створити низку методів, зокрема аквананотехнологію, що базується на ерозивно-вибуховій технології (Пат. 35582 України). Ця технологія уможливила промислове виробництво цитратів металів із високим ступенем чистоти та вільних від наночасток (Пат. 39392 України). Низка дослідників (Borysevych et al., 2010) відмічають високу біологічну активність цитратів металів щодо рослинних об'єктів, мікроорганізмів і тварин. Стосовно впливу цитратів металів, отриманих методом аквананотехнологій, на біологію ксилотрофних базидісвих грибів у культурі існують лише фрагментарні дані (Klechak et al., 2013; Al-Maali, 2015), які вказують на перспективність більш глибоких досліджень.

Значну роль у фізіології живлення грибів відіграють іони есенціальних мікроелементів. Одні з найважливіших для повноцінного функціонування еукаріотичної клітини - мікроелементи цинк, купрум і манган (Banci, 2013). Цинк має фундаментальне значення для всіх сфер життя, оскільки він входить до складу каталітичних і структурних центрів великого масиву білків. Це єдиний метал, який трапляється у ферментах усіх класів (Broadley et al., 2007). Майже $25 \%$ цинк-зв'язаних білків пов'язано із транскрипційною регуляцією (Staats et al., 2015). Більшість окисно-відновних реакцій у клітині відбувається за участі ферментів, що містять іони феруму, купруму чи мангану в координаційному центрі (Kaim et al., 2013). Манган як кофактор входить до складу ферментів, які каталізують гідролітичні та окисно-відновні реакції (Law et al., 2008). Серед цих ферментів основну роль відіграють манган-залежна супероксиддисмутаза, різні каталази та пероксидази (Kaim et al., 2013). Купрум входить до складу низки ключових ферментів, необхідних для повноцінного функціонування будь-якої еукаріотичної клітини, насамперед, до цитохром с-оксидази, супероксиддисмутази та численних купрумумісних оксидаз (Banci, 2013).

Результати, отримані у попередньому дослідженні (Al-Maali, 2015), свідчили про більшу біологічну активність цитратів цинку, мангану та купруму, порівняно з відповідними сульфатами, щодо росту міцелію T. versicolor 353. Із метою пояснення ефекту збільшення біомаси цього штаму за впливу зазначених цитратів металів (порівняно із сульфатами відповідних металів) досліджували параметри засвоєння джерела карбону та нітрогену, ступінь акумуляції міцелієм іонів цих металів, а також їх вплив на синтез екзополісахаридів міцеліем T. versicolor 353.

\section{Матеріал і методи досліджень}

У дослідженнях використовували високопродуктивний штам T. versicolor 353 з Колекції культур шапинкових грибів Інституту ботаніки імені М. Г. Холодного НАН України (Bisko, 2016). Штам обрано за результатами скринінгу біотехнологічно цінних штамів T. versicolor, проведеного Л. О. Антоненко.

В усіх дослідженнях як контроль використовували живильне середовище такого складу $\left(\Gamma / \mathrm{дm}^{3}\right)$ : глюкоза -25 , пептон - 3, дріжджовий екстракт - 3, $\mathrm{K}_{2} \mathrm{HPO}_{4}-1, \mathrm{KH}_{2} \mathrm{PO}_{4}-1, \mathrm{MgSO}_{4} \cdot 7 \mathrm{H}_{2} \mathrm{O}-0,25$,

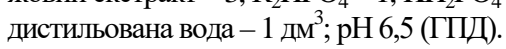

У контрольному середовищі містилася кількість мікроелементів (у складі пептону та дріжджового екстракту), необхідних для мінімального росту міцелію: цинку 473,2 мкг/дм³ ${ }^{3}$ мангану 5,1 мкг/дм ${ }^{3}$, купруму 7,8 мкг/дм³.

У дослідних варіантах до живильного середовища ГПД додавали іони цинку $\left(1 \mathrm{mг} /\right.$ дм $\left.^{3}\right)$, мангану $\left(1 \mathrm{mг} /\right.$ дм $\left.^{3}\right)$ або купруму $\left(4 \mathrm{mг} /\right.$ дм $\left.^{3}\right)$ у вигляді цитрату, отриманого методом аквананотехнології. Використані концентрації - оптимальні для накопичення біомаси, що встановлено під час попереднього дослідження (AlMaali, 2015). Усі цитрати металів отримані методом аквананотехнології (Пат. 39392 України) в Українському державному науково-дослідному Інституті нанобіотехнологій і ресурсозбереження Державного агентства резерву України.

Для коректної інтерпретації результатів ставили дослід з аналогічними концентраціями відповідного іона металу у формі сульфату. Сульфати металів - стандартний компонент живильних середовищ культивування грибів (Dudka, 1982). Для аналізу впливу цитратів і сульфатів металів на біохімічні та фізіологічні параметри біомаси, досліджуваний штам культивували в умовах глибинної культури.

Міцелій вирощували 9 діб на лабораторних качалках (120 об./хв), за температури $26 \pm 1^{\circ} \mathrm{C}$, у колбах Ерленмеєра, об’ємом $250 \mathrm{~cm}^{3}$, що містили $50 \mathrm{~cm}^{3}$ живильного середовища. Інокуляцію проводили у дві стадії:

1) інокулюм для попередньої культури отримували упродовж семи діб на ГПД середовищі з 20 г/дм ${ }^{3}$ агар-агару, стерильно гомогенізували та вносили у рідке живильне середовище з розрахунку 10\% від об'єму;

2) попередню культуру отримували упродовж п'яти діб в умовах глибинної культури (120 об./хв, $\left.26 \pm 1^{\circ} \mathrm{C}\right)$ та використовували для інокуляції дослідних серій із розрахунку $10 \%$ загального об’ $є-$ му живильного середовища.

Отриману у процесі культивування біомасу фільтрували, промивали, висушували до постійної маси за $105{ }^{\circ} \mathrm{C}$ та зважували. Абсолютно суху масу (АСМ) визначали за формулою:

$$
M=M_{b}-M_{\hat{\mathrm{i}}} \text {, }
$$

де $M$ - абсолютно суха маса міцелію (г), $M_{b}$ - маса висушеного за $105^{\circ} \mathrm{C}$ міцелію, отриманого у процесі культивуваня (г), $M_{i}-$ маса висушеного за $105^{\circ} \mathrm{C}$ інокулюму, використаного для інокуляції дослідних серій (г).

Загальний азот визначали в абсолютно сухій біомасі методом К’єльдаля (Latimer, 2012).

Кількість використаної глюкози визначали таким чином. Концентрацію глюкози у середовищі на 9-ту добу культивування міцелію визначали за допомогою глюкооксидазної тест-системи. Кількість спожитої глюкози розраховували за модифікованою нами формулою:

$$
S=K_{1}-K_{2} \frac{V_{1}}{V_{2}},
$$

де $S$ - кількість використаної глюкози (г/дм $\left.{ }^{3}\right), K_{1}$ - концентрація глюкози у середовищі до культивування (г/дм $\left.{ }^{3}\right), \mathrm{K}_{2}-$ концентрація 
глюкози у середовищі після культивування (г/дм³), $\mathrm{V}_{1}$ - об'єм середовища після культивування (дм $\left.{ }^{3}\right), \mathrm{V}_{2}-$ об'єм середовища до початку культивування (дм $\left.{ }^{3}\right)$.

Економічний коефіцієнт використання глюкози на синтез біомаси (або екзополісахаридів) визначали за формулою (Pert, 1978):

$$
E K=\frac{M}{S} 100 \% \text {, }
$$

де $E K$ - економічний коефіцієнт (\%), $M$ - абсолютна суха маса міцелію (або екзополісахаридів, г/дм ${ }^{3}$ ), $S$ - кількість використаної глюкози (г/дм $\left.{ }^{3}\right)$.

Спожитий азот розраховували за формулою:

$$
W=\left(N_{\text {total }}\right) M,
$$

де $W$ - спожитий азот (г/дм $\left.{ }^{3}\right), M$ - абсолютна суха маса міцелію $\left(г / \mathrm{MM}^{3}\right), N_{\text {total }}-$ загальний азот в абсолютно сухій біомасі (г/ г АCM).

Процент використаного міцелієм азоту з живильного середовища визначали за формулою:

$$
A=\frac{\left(N_{\text {total }}\right) M}{N_{\text {substrat }}},
$$

де $A$ - кількість використаного міцелієм азоту (\%), $N_{\text {total }}$ - загальний азот в абсолютно сухій біомасі (г/Г АСМ), $M$ - абсолютна суха маса міцелію (г/дм $\left.{ }^{3}\right), N_{\text {substrat }}$ - концентрація азоту в живильному середовищі до культивування (г/дм³).

Кількість мікроелементів, акумульованих міцелієм, визначали методом оптично-емісійної спектроскопії з індуктивно зв'язаною плазмою на приладі Optima 2100 DV (Perkin Elmer, США). Загальну акумуляцію мікроелемента розраховували за формулою:

$$
T=R M,
$$

де $T$ - загальна акумуляція мікроелемента (мкг/дм $\left.{ }^{3}\right), R$ - концентрація мікроелемента в міцелії (мкг/г АCM), $M$ - абсолютно суха маса міцелію (г/дм $\left.{ }^{3}\right)$. Для кількісного визначення екзополісахаридів відфільтровану від залишків міцелію культуральну рідину упа- рювали утричі та осаджували полісахариди 96\% етиловим спиртом, у співвідношенні $1: 2$ (за об’ємом) упродовж 24 годин за $4{ }^{\circ} \mathrm{C}$. Осад відфільтровували за 3000 g упродовж 15 хвилин і ресуспензували у гарячій дистильованій воді $\left(90^{\circ} \mathrm{C}\right)$. Отриманий розчин діалізували проти дистильованої води упродовж доби. Отриману фракцію полісахаридів висушували до постійної ваги за $60^{\circ} \mathrm{C}$. Кількість полісахаридів визначали гравіметрично (Bisko, 2012). Отримані результати виражали в розрахунку на об’єм культуральної рідини або у перерахунку на кількість синтезованої у відповідному досліді біомаси. Аналіз проведено за допомогою прикладного програмного пакета Statistica 6.0 (StatSoft Inc., USA).

\section{Результати}

Використання джерела вуглецю T. versicolor 353 на живильних середовищах із цитратами або сульфатами різних металів. У нашому дослідженні міцелій T. versicolor 353 культивували на живильному середовищі, що містило в ролі основного джерела карбону глюкозу. Тому кількісний аналіз спожитої глюкози - основний метод оцінювання впливу цитратів і сульфатів металів на ступінь використання субстрату. Упродовж 9 діб культивування міцелію на контрольному середовищі без досліджуваних металів T. versicolor 353 використав 74,4\% глюкози від iï початкової концентрації (табл. 1).

Цитрати та сульфати мангану та цинку суттєво не впливали на ступінь використання глюкози міцелієм T. versicolor 353, відносно контролю (табл. 1). Натомість, під час культивування міцелію T. versicolor 353 на середовищі із сульфатом купруму, ступінь використання глюкози зростав до $83,6 \%$, а на середовищі із цитратом купруму - до 94,8\% (табл. 1).

\begin{tabular}{|c|c|c|}
\hline Живильне середовище ${ }^{3}$ & Біомаса, $\mathrm{r} /$ дм $^{3}$ & Кількість використаної глюкози, г/дм³ \\
\hline ГПД & $4,77 \pm 0,21$ & $18,6 \pm 0,54$ \\
\hline ГПД + сульфат цинку $\left(\mathrm{Zn}^{2+} 1\right.$ мг/дм³) & $5,79 \pm 0,23 *$ & $19,4 \pm 0,54$ \\
\hline ГПД + цитрат цинку $\left(\mathrm{Zn}^{2+} 1\right.$ мг/дм³) & $6,52 \pm 0,03 * * *$ & $19,6 \pm 0,51$ \\
\hline ГПД + сульфат мангану $\left(\mathrm{Mn}^{2+} 1 \mathrm{мг} /\right.$ дм³) & $5,05 \pm 0,32$ & $19,2 \pm 0,58$ \\
\hline ГПД + цитрат мангану $\left(\mathrm{Mn}^{2+} 1 \mathrm{mг} / \mathrm{дм}^{3}\right)$ & $6,15 \pm 0,23 * *$ & $19,1 \pm 0,52$ \\
\hline ГПД + сульффат купруму $\left(\mathrm{Cu}^{2+} 4\right.$ мг/дм³) & $7,10 \pm 0,06 * * *$ & $20,9 \pm 0,61^{*}$ \\
\hline ГПД + цитрат купруму $\left(\mathrm{Cu}^{2+} 4 \mathrm{Mr} /\right.$ дм $\left.^{3}\right)$ & $8,58 \pm 0,19 * * *$ & $23,7 \pm 0,55 * *$ \\
\hline
\end{tabular}

\section{Таблиця 1}

Вплив цитратів ${ }^{1}$ і сульфатів металів на синтез біомаси та параметри використання глюкози у живильному середовищі ${ }^{2}$ міцелієм T. versicolor $353(\mathrm{n}=4, \mathrm{x} \pm \mathrm{SE})$

Примітки: ${ }^{1}$ - цитрати металів, синтезовані методом аквананотехнології; ${ }^{2}$ - початкова концентрація глюкози в живильному середовищі становила 25 г/дм ${ }^{3}$; 3 - оптимальні концентрації цитратів металів, визначені у попередніх статтях (Al-Maali, 2015; Al-Maali et al., 2016a, 2016b); ${ }^{4}$ - живильне середовище 3 глюкозою, пептоном і дріжджовим екстрактом; * $-\mathrm{P}<0,05,{ }^{* *}-\mathrm{P}<0,01$, *** $-\mathrm{P}<0,001$ порівняно $з$ контролем.

Акумуляція мікроелементів міцелісм T. versicolor 353 на живильних середовищах із цитратами або сульфатами різних металів. Концентрація цинку в міцелії T. versicolor 353 на контрольному середовищі становила 28,8 мкг/г абсолютно сухої ваги (табл. 2). Такий рівень іонів цинку в міцелії пов’язаний із високим фоновим рівнем цього мікроелемента в самому середовищі (у складі дріжджового екстракту та пептону). Проте використання середовища без іонів цинку виявилось неможливим у зв'язку з відсутністю росту міцелію. У подальшому аналізі результатів, от- риманих у дослідах із цинком, мова буде йти саме про додатково додані концентрації іона в різних формах.

Додавання у живильне середовище цитрату цинку викликало збільшення концентрації цинку в біомасі $T$. versicolor 353 на 203,9\% порівняно з контролем. У випадку заміни цитрату цинку у середовищі на сульфат цинку у відповідній концентрації акумуляція цього мікроелемента збільшується на 230,6\%. Проте акумуляція цинку міцелієм $T$. versicolor 353 у сульфатній формі не була достовірно вищою порівняно із цитратною формою (табл. 2).

\begin{tabular}{|c|c|c|c|}
\hline Параметри & ГПД ${ }^{2}$ (контроль) & $\begin{array}{c}\text { ГПД + сульфат } \\
\text { мікроелемента }\end{array}$ & $\begin{array}{c}\text { ГПД + цитрат } \\
\text { мікроелемента }^{3}\end{array}$ \\
\hline Концентрація цинку, мкг/г АСМ & $28,77 \pm 0,58$ & $95,12 \pm 3,07^{\mathrm{a}}$ & $87,44 \pm 1,75^{\mathrm{a}}$ \\
\hline Загальна кількість цинку в біомасі, отримана 31 дм³ живильного середовища, мкг & $137,23 \pm 4,64$ & $550,74 \pm 18,54^{\mathrm{a}}$ & $570,11 \pm 8,24^{\mathrm{a}}$ \\
\hline Концентрація мангану, мкг/г АCM & $1,07 \pm 0,19$ & $70,51 \pm 4,40^{\mathrm{a}}$ & $56,50 \pm 6,90^{\mathrm{a}}$ \\
\hline Загальна кількість мангану в біомасі, отримана 31 дм живильного середовища, мкт & $5,10 \pm 0,65$ & $356,08 \pm 20,22^{\mathrm{a}}$ & $347,48 \pm 31,17^{\mathrm{a}}$ \\
\hline Концентрація купруму, мкг/г АCM & $1,63 \pm 0,22$ & $82,98 \pm 4,59$ ab & $162,03 \pm 3,24$ ab \\
\hline 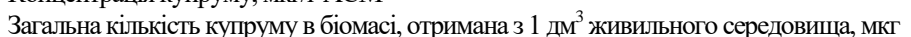 & $7,78 \pm 2,37$ & $589,16 \pm 49,69$ ab & $1390,22 \pm 26,70^{\mathrm{ab}}$ \\
\hline
\end{tabular}

\section{Таблиця 2}

Акумуляція іонів цинку, купруму та мангану міцелієм T. versicolor 353 на ГПД-середовищі з різними джерелами відповідних металів ${ }^{1}(\mathrm{n}=4, \mathrm{x} \pm \mathrm{SE})$

Примітки: ${ }^{1}$ - оптимальні конщентрації цитратів металів, визначені у попередніх працях (Al-Maali, 2015; Al-Maali et al., 2016a, 2016b) i становлять Zn ${ }^{2+}-1$ мг/дм ${ }^{3}$, $\mathrm{Mn}^{2+}-1 \mathrm{Mг} / \mathrm{дм}^{3}, \mathrm{Cu}^{2+}-1 \mathrm{mг} / \mathrm{дм}^{3}{ }^{2}{ }^{2}$ - живильне середовище 3 глюкозою, пептоном і дріжджовим екстрактом; ${ }^{3}$ - цитрати металів, синтезовані методом аквананотехнології; ${ }^{\mathrm{a}}$ - достовірна $(\mathrm{P}<0,001)$ різниця, порівняно 3 контролем; ${ }^{\mathrm{b}}$ - достовірна $(\mathrm{P}<0,001)$ різниця, порівняно $з$ дослідом із солями відповідного металу. 
На середовищі із цитратом цинку біомаса $T$. versicolor 353 вища, ніж на середовищі із сульфатом цинку (табл. 1). Достовірної різниці загальної акумуляції іонів цинку (у розрахунку на всю біомасу, отриману з рівних об’ємів середовища) на середовищах із цитратом або сульфатом цинку не виявлено, різниця між цими значеннями не виходила за межі статистичної похибки (табл. 2).

Концентрація іонів мангану в міцелії на контрольному живильному середовищі становила 1,07 мкт/г АСМ (табл. 2). На середовищі із цитратом мангану акумуляція цього мікроелемента зростала у 56 разів порівняно 3 контролем, а на середовищі 3 сульфатом мангану - у 70 разів більша (табл. 2). Як і у випадку з цитратом і сульфатом цинку, достовірної різниці концентрації мікроелемента (мангану) в міцелії T. versicolor 353 на різних середовищах не виявлено. Загальна акумуляція мангану (у розрахунку на всю біомасу, отриману з рівного об’єму середовища) також виявилась у межах статистичної похибки.

Концентрація іонів купруму в міцелії в контрольному досліді становила 1,6 мкг/г АСМ, у досліді із сульфатом купруму - 83,0, а в досліді із цитратом цього металу - 162,0 мкт/г АСМ, що майже вдвічі більше, порівняно з експериментом, в якому до живильного середовища додавали сульфат купруму (табл. 2). Враховуючи зростання біомаси та загальну акумуляцію купруму міцелієм на середовищі із цитратом купруму ця закономірність не змінюється: міцелій $T$. versicolor 353 акумулює іони купруму у формі цитрату краще, аніж у сульфатній формі (табл. 2).

Використання джерела нітрогену на середовищах із цитратами або сульфатами металів. Основні джерела нітрогену у живильному середовищі для культивування T. versicolor $353-$ дріжджовий екстракт і бактеріальний пептон. Загальна кількість азоту в початковому живильному середовищі становила 0,756 г/дм³.

На контрольному живильному середовищі міцелій T. versicolor 353 асимілював 17,7\% нітрогену 3 живильного середовища (рис. 1). У дослідах із використанням сульфату мангану та сульфату цинку не виявлено статистично значимого впливу на ступінь асиміляції нітрогену міцелієм порівняно 3 контролем. На середовищах із цитратом мангану або цитратом цинку, міцелій T. versicolor 353 асимілював достовірно вищу кількість нітрогену з живильного середовища.

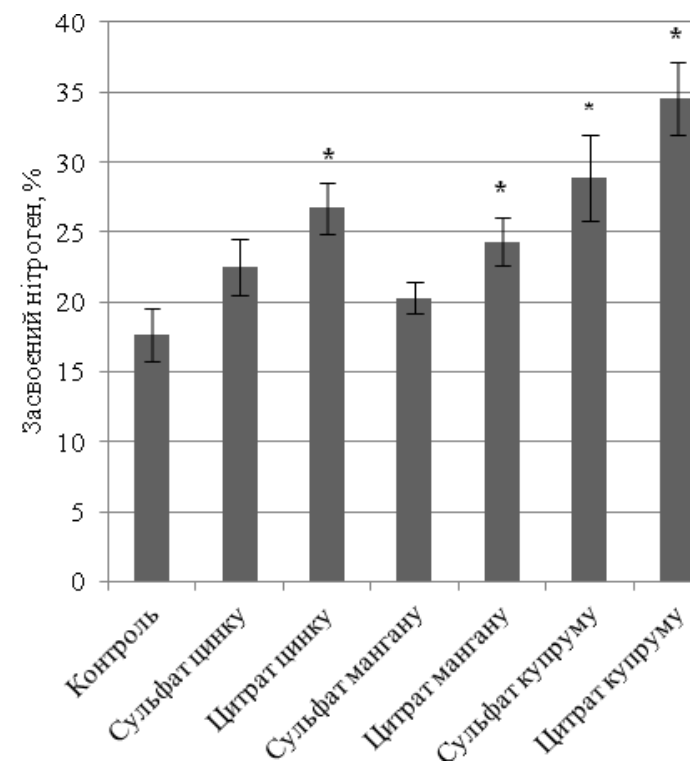

Pис. 1. Концентрація засвоєного нітрогену міцелієм T. versicolor

353 на ГПД-середовищі із цитратами та сульфатами різних металів: цитрати металів, синтезовані методом

аквананотехнології; оптимальні концентрації іонів металів

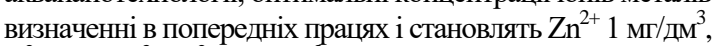
$\mathrm{Mn}^{2+} 1 \mathrm{мг} / \mathrm{дм}^{3}, \mathrm{Cu}^{2+} 4 \mathrm{мг} /$ дм$^{3} ; *$ - достовірна $(\mathrm{P}<0,05)$ різниця, порівняно $з$ контролем; $\mathrm{n}=4, \mathrm{x} \pm \mathrm{SE}$

У дослідах із T. versicolor 353 на середовищах із цитратом i сульфатом купруму встановлено інші закономірності. Викорис- тання нітрогену міщелієм суттєво зростало, як на середовищі із сульфатом купруму (28,9\%), так і $з$ цитратом купруму (34,5\%).

Синтез екзополісахаридів на середовищах із цитратами або сульфатами металів. Дані, отримані у процесі аналізу кількості екзополісахаридів у культуральній рідинні, одночасно розраховували на одиницю живильного середовища та на одиницю АСМ, отриману у відповідному досліді.

На живильному середовищі із цитратом цинку загальна кількість екзополісахаридів у культуралній рідині була майже на $29 \%$ вищою порівняно з контрольним значенням (рис. 2). Але кількість екзополісахаридів, синтезованих на одиницю біомаси (на середовищі із цитратом цинку), становила $0,42 \pm 0,02$ мг г АСМ, що дорівнює значенням, отриманим на контрольному середовищі $(0,45 \pm$ 0,03 мг/Г АСМ). Таким чином, зростання синтезу екзополісахаридів на середовищі із цитратом цинку корелює зі зростанням біомаси міцелію T. versicolor 353.

На середовищі із сульфатом цинку міцелій T. versicolor 353 продукував $0,32 \pm 0,02$ мГ екзополісахаридів на 1 г АCM, що на 28,0\% менше порівняно з контролем. У цьому випадку кількість екзополісахаридів у культуральній рідині статистично не відрізнялась від їх кількості в конрольному експерименті.

Іони мангану в обох формах (цитратній та сульфатній) певною мірою пригнічували синтез екзополісахаридів T. versicolor 353. Сульфат мангану знижував кількість екзополісахаридів у культуральній рідині на $35 \%$ відносно контролю (рис. 2). Хоча в дослідах iз цитратом мангану не зафіксовано статистично достовірного впливу на загальну кількість екзополісахаридів у культуральній рідині (рис. 2), він пригнічував синтез екзополісахаридів у розрахунку на одиницю АСМ. У контрольному досліді на 1 г АСМ міцелій синтезував $447 \pm 34$ мг екзополісахаридів. На середовищах із цитратом або сульфатом цинку цей показник майже на $40 \%$ менший відносно контролю $(0,30 \pm 0,02$ та 0,28 $\pm 0,02$ мг/Г АСБ відповідно).

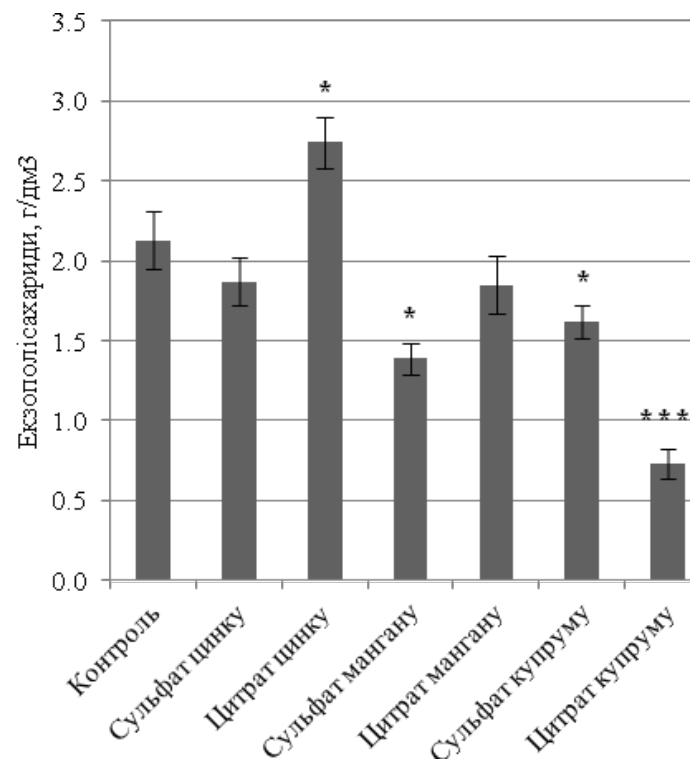

Рис. 2. Вплив цитратів і сульфатів цинку, мангану та купруму на кількість екзополісахаридів у культуральній рідині T. versicolor 353: цитрати металів, синтезовані методом аквананотехнології; оптимальні концентрації іонів металів визначенні в попередніх публікаціях: $\mathrm{Zn}^{2+} 1 \mathrm{мг} / \mathrm{дм}^{3}, \mathrm{Mn}^{2+} 1 \mathrm{мг} / \mathrm{дм}^{3}, \mathrm{Cu}^{2+} 4 \mathrm{мг} / \mathrm{дм}^{3}$;

*_- $\mathrm{P}<0,05,{ }^{* *}-\mathrm{P}<0,01, * * *-\mathrm{P}<0,001$ порівняно 3 контролем; $\mathrm{n}=4, \mathrm{x} \pm \mathrm{SE}$

Додавання до живильного середовища іонів купруму в обох формах (цитратній і сульфатній) суттєво пригнічувало синтез екзополісахаридів у культуральній рідині (рис. 2). Загальна кількість екзополісахаридів у культуральній рідині зменшувалася на 24\% за дії сульфату купруму та 66\% - за дії цитрату купруму порівняно 3 контролем. Відповідно зменшувався синтез екзополісахаридів на одиницю АСМ. На середовищі із сульфатом купруму, на 1 г АСМ T. versicolor 353 синтезував $0,23 \pm 0,02$ мг екзополісахаридів, тобто 
на 51\% менше, ніж на контрольному середовищі. На середовищі із сульфатом купруму цей показник скорочувався ще сильніше: 0,09 \pm 0,01 мг/г АCM, на 81\% менше порівняно з контролем.

\section{Обговорення}

Під час попередніх досліджень (Al-Maali, 2015; Al-Maali et al, 2016a, 2016b) отримано результати, засвідчили про більшу біологічну активність цитратів вищезазначених металів порівняно 3 відповідними сульфатами. Для глибшого розуміння фізіологічних змін, індукованих цитратами металів, які викликали збільшення біомаси зазначених видів, доцільно дослідити зміни процесів засвоєння основних складових живильного середовища. Аналізуючи наведені дані, ми намагалися відповісти на такі питання: (1) чи існує взаємозв'язок між ступенем засвоєння мікроелементів міцелієм T. versicolor 353 від форми, в якій цей мікроелемент був внесений до живильного середовища; (2) чи існує взаємозв'язок між джерелом мікроелемента та ступенями використання джерел карбону та нітрогену міцелієм T. versicolor 353; (3) як впливають джерело та рівень акумуляції зазначених мікроелементів на синтез біомаси та полісахаридів міцелієм T. versicolor 353 ?

Результати дослідів із цитратом і сульфатом купруму свідчать про наявність прямої лінійної залежності між синтезом біомаси T. versicolor 353 і кількістю використаної глюкози (рис. 3).

Концентрація іонів купруму в обох випадках однакова, становила 4 мг/дм ${ }^{3}$. Таким чином, заміна сульфату купруму в середовищі на цитрат купруму викликала зростання біомаси міцелію за рахунок ефективнішого засвоєння глюкози 3 живильного середовища. Подібної залежності не виявлено у дослідах із цитратами та сульфатами мангану та цинку. Але у цих випадках за незмінного споживання глюкози (табл. 1) зафіксовано зростання біомаси за додавання до середовища цитрату цинку або цитрату мангану (табл. 1) порівняно $з$ контролем. Таким чином, доцільно проаналізувати вплив досліджуваних цитратів і сульфатів металів на економічний коефіцієнт споживання глюкози.

Клітини використовують глюкозу не тільки як джерело карбону, а і як універсальне джерело енергії. У випадку закритої системи без зовнішньої подачі енергії джерело вуглецю може (1) залишитися у середовищі, (2) бути використаним на синтез біомаси або (3) на синтез енергії, тобто перетворене на $\mathrm{CO}_{2}$ у процесі дихання. Це можна розрахувати як різницю між першим і другим, що виражається економічним коефіцентом. Таким чином, економічний коефіцієнт (ЕК), який розраховано як співвідношення синтезованої біомаси до кількості спожитої глюкози, дає змогу оцінити ступінь використання глюкози на енергетичні та пластичні процеси. За літературними даними, економічний коефіцієнт для різних видів грибів коливається від 15\% до 56\% і залежить від біологічних особливостей штаму, умов культивування та складу живильного середовища (Bisko et al., 2012; Titova and Klechak, 2015).

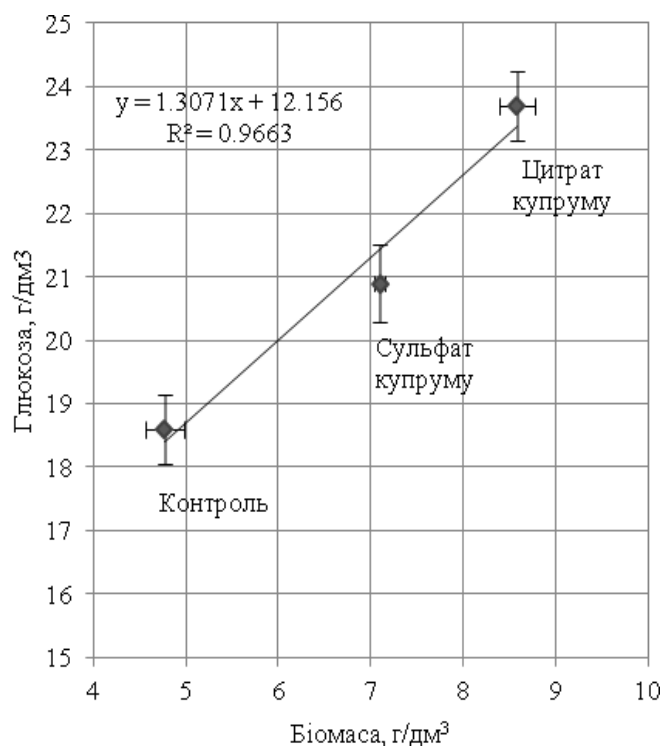

Рис. 3. Залежність між біомасою T. versicolor 353 і ступенем використання глюкози на середовищах з іонами купруму $\left(4 \mathrm{Mг} /\right.$ дм $\left.^{3}\right)$ у формі цитратної та сульфатної солі: початкова концентрація глюкози у живильному середовищі становила

$$
25 \text { г/дм }{ }^{3} \text {; цитрати металів синтезовані методом }
$$
аквананотехнології; $n=4, x \pm S E$

Під час культивування T. versicolor 353 на контрольному живильному середовищі ЕК становив 25,6\% (рис. 4). Тобто близько чверті використаної глюкози йшло на синтез біомаси, а три чверті iї використано для енергетичних потреб.

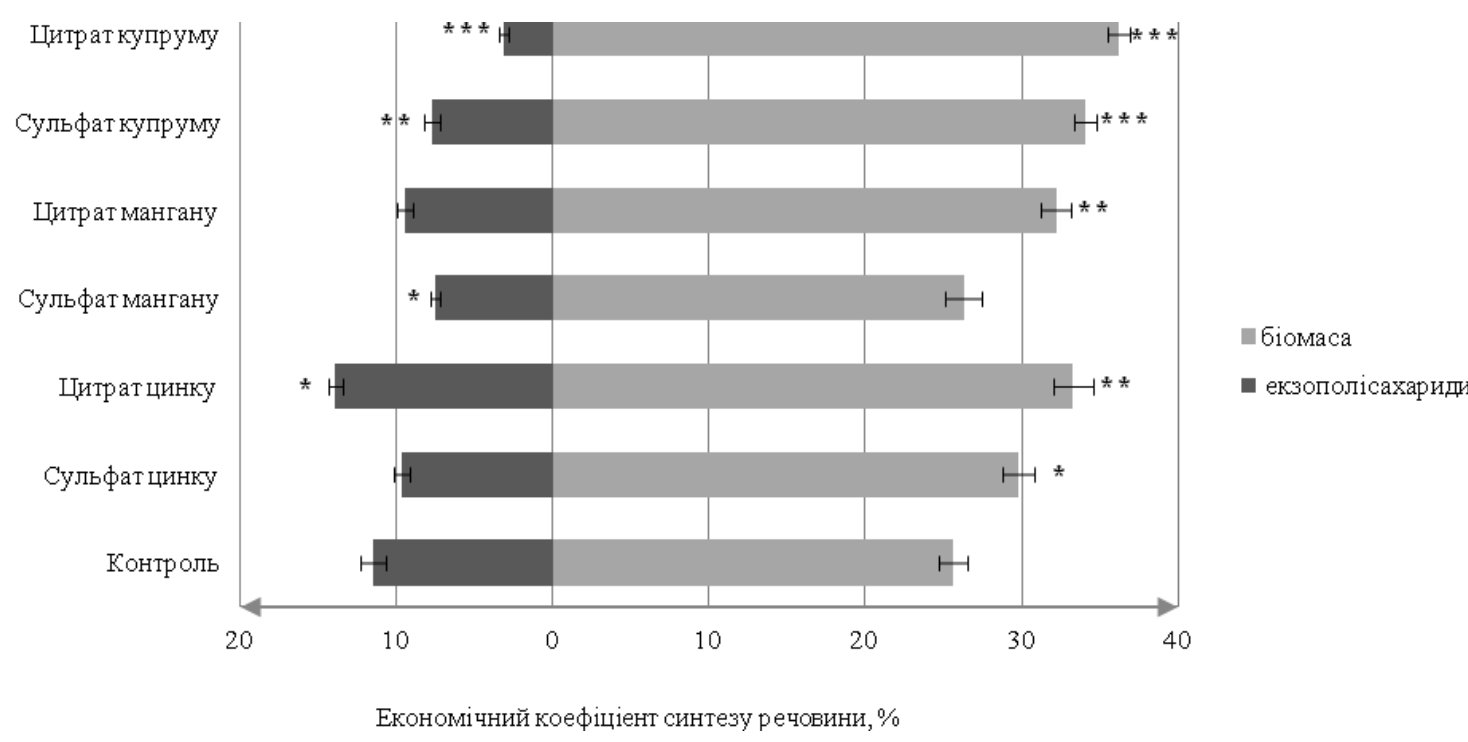

Рис. 4. Економічний коефіцієнт синтезу біомаси (\%) та екзополісахаридів (\%) міцелієм T. versicolor 353 на середовищах із додаванням цитратів, синтезованих методом аквананотехнології, або сульфатів різних металів: ${ }_{*}-\mathrm{P}<0,05,{ }^{*}$ - $\mathrm{P}<0,01,{ }^{* * *}-\mathrm{P}<0,001$ порівняно $з$ контролем; $\mathrm{n}=4, \mathrm{x} \pm \mathrm{SE}$

Додавання до середовища сульфату мангану суттєво не впливає на цей баланс (рис. 5). Сульфат цинку, доданий до живильного середовища, певною мірою підвищує економічний коефіцієнт синтезу біомаси (рис. 4). Водночас, цитрати мангану та цинку впливають на економічний коефіцієнт ефективніше, ніж сульфати відповідних металів (рис. 4). Ці дані свідчать, що додавання цитра- 
тів цих металів до середовища сприяє оптимізації процесів використання енергії та певною мірою змінює баланс між енергетичними затратами та синтезом біомаси. Ще більшою мірою цей процес зрушується на користь синтезу біомаси за додавання до живильного середовища сульфату та цитрату купруму. Економічний коефіцієнт синтезу біомаси на середовищі із сульфатом купруму зростав до 34,0\%, а на середовищі із цитратом купруму - до 36,2\% (рис. 4). Таким чином, накопичуючи однакову кількість іонів цинку, на середовищах із різними джерелами цього елемента, міцелій T. versicolor 353 синтезує різну кількість біомаси. Отримані дані свідчать, що на одиницю засвоєних іонів цинку в цитратній формі T. versicolor 353 синтезує більше біомаси, ніж на одиницю засвоєних іонів цинку у формі сульфату. У дослідах із цитратом цинку на 1 мкг засвоєних іонів цинку синтезується 75 мг біомаси, на цей процес використовується 204 мг глюкози. В експерименті із сульфатом цинку це співвідношення виглядає так:

1 мкг $\mathrm{Zn}^{2+} \rightarrow 61$ мг біомаси $\rightarrow 224$ мг глюкози.

На контрольному середовищі, в якому отримана найменша біомаса міцелію (табл. 1), це співвідношення виглядає так:

1 мкг $\mathrm{Zn}^{2+} \rightarrow 166$ мг біомаси $\rightarrow 647$ мг глюкози.

Тобто на бідному за вмістом цинку середовищі недостатність іонів цинку компенсується суттєвим зростанням енергетичних витрат за рахунок збільшення потреб у глюкозі, що відображається на низьких показниках синтезу загальної біомаси міцелію.

Подібні результати отримано у дослідах із цитратом і сульфатом мангану. На середовищі із цитратом мангану на 1 мкг засвоєних іонів синтезується 109 мг біомаси T. versicolor 353, і на цей процес використовується 338 мг глюкози. На середовищі із сульфатом мангану на 1 мкг засвоєних іонів синтезується лише 72 мг біомаси і використовується 272 мг глюкози.

На контрольному середовищі, в якому манган був у кількості 5,1 мкг/дм³ , це співвідношення мало такий вигляд:

1 мкг $\mathrm{Mn}^{2+} \rightarrow 935$ мг біомаси $\rightarrow 3647$ мг глюкози. Як і у попередньо описаному досліді із цинком, недостатність іонів мангану компенсувалася суттєвим зростанням енергетичних витрат за рахунок збільшення потреб у глюкозі, що і відобразилося в низьких показниках синтезу біомаси міцелію (табл. 1).

У дослідах із вивчення акумуляції іонів купруму міцелієм T. versicolor 353 виявлено інші закономірності. Результати наших експериментів вказують на пряму залежність між кількістю накопичених іонів купруму та кількістю синтезованої біомаси (рис. 5).

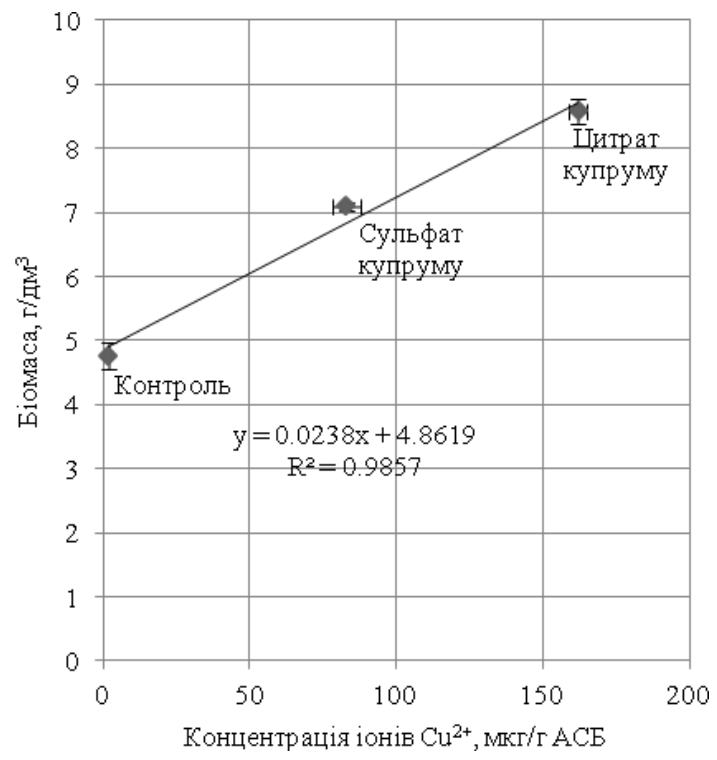

Рис. 5. Залежність між біомасою T. versicolor 353 та концентрацією іонів купруму в абсолютно сухій біомасі на середовищах з іонами купруму (4 мг/дм³ $\left.{ }^{3}\right)$ у формі цитратної та сульфатної солі: концентрація іонів купруму в контрольному живильному середовищі становила 7,8 мкг/дм³; цитрати металів синтезовані методом аквананотехнологіi; $n=4, \mathrm{x} \pm \mathrm{SE}$
Процес культивування T. versicolor 353 на живильних середовищах із різними джерелами іонів купруму характеризується двома закономірностями: перша відображає пряму залежність між накопиченням біомаси та використанням джерела вуглецю (рис. 3), друга - пряму залежність між накопиченням біомаси та акумуляцією іонів купруму (рис. 5). Наступні числові співвідношення результат зведення цих двох закономірностей. На середовищі із цитратом купруму на 1 мкг засвоєних іонів купруму синтезується 53 мг біомаси, за використання 141 мг глюкози (загальний приріст біомаси - 79,9\% порівняно з контролем). На середовищі із сульфатом купруму залежність виглядає так:

1 мкг $\mathrm{Cu}^{2+} \rightarrow 86$ мг біомаси $\rightarrow 251$ мг глюкози

за загального приросту біомаси 48,9\% відносно контролю. Аналіз цих даних свідчить, що на середовищі із сульфатом купруму на одиницю засвоєних іонів купруму синтезується більше біомаси, але це відбувається за рахунок суттєвого зростання потреб у глюкозі та негативно (порівняно із цитратом купруму) відображається на загальному прирості біомаси.

Ці закономірності доводять, що, по-перше, цитрат купруму краще джерело іонів купруму для росту міцелію T. versicolor 353, ніж сульфат, по-друге, збільшення кількості біодоступних іонів купруму викликає зростання біомаси $T$. versicolor 353 за рахунок ефективнішого використання джерела карбону (глюкози) на синтез одиниці біомаси.

Додавання до середовища іонів усіх використаних у дослідженні металів впливало на співвідношення використаного нітрогену до використаного карбону. На контрольному середовищі це співвідношення становило $1: 56$, на середовищі із сульфатом цинку $-1: 46$, на середовищі із цитратом цинку $1: 39$, на середовищі із сульфатом мангану $-1: 51$, а на середовищі із цитратом мангану $-1: 42$.

Як зазначено вище, цитрат та сульфат купруму підвищували споживання карбону пропорційно до збільшення біомаси міцелію. Співвідношення між використаним нітрогеном і карбоном мало такий вигляд: 1 : 38 на середовищі із сульфатом цинку і 1 : 36 на середовищі із цитратом цинку. Ці дані свідчать, що, як і у випадку зі споживанням глюкози, інтенсивність процесу асиміляції нітрогену зросла прямо пропорційно зі збілышенням біомаси T. versicolor 353. Таким чином, відносно контролю обидві форми купруму рівномірно збільшують здатність міцелію використовувати джерела нітрогену та карбону. Цитрат купруму впливав на обидва процеси інтенсивніше, ніж сульфат купруму.

Вплив цитратів або сульфатів металів на синтез екзополісахаридів. Розрахунок витрат глюкози на синтез екзополісахаридів вказує, що ефективність їх синтезу на 1 г використаної глюкози зростала на 22\% на середовищі із цитратом цинку порівняно 3 контролем. У той же час, на середовищі із сульфатом цинку цей показник зменшувався на 16\%. На контрольному середовищі на 1 г використаної глюкози міцелій $T$. versicolor 353 продукував $114,5 \pm 8,3$ мг екзополісахаридів, на середовищі із сульфатом цинку -96,4 \pm 6,8 мг, а на середовищі із цитратом - 139,8 \pm 8,9 мг.

Найвищий показник синтезу екзополісахаридів на 1 мг засвоєного нітрогену спостерігали під час культивування T. versicolor 353 на контрольному середовищі. У цьому випадку на 1 мг асимільованого нітрогену міцелій продукував $15,9 \pm 1,4$ мг екзополісахаридів, тоді як на середовищах із сульфатом цинку - тільки $11,0 \pm 0,9$ мг, а на середовищі із цитратом - 13,8 \pm 0,8 мг.

Ефективність синтезу екзополісахаридів на 1 мкг акумульованого цинку на середовищі із цитратом цинку була вищою порівняно із середовищем, що містило сульфат цинку. На середовищі із цитратом цинку міцелій T. versicolor 353 продукував 31,3 мг екзополісахаридів на 1 мкг акумульованих іонів цинку, а на середовищі із сульфатом цинку - тільки 19,6 мг на 1 мкг іонів.

Ефективність синтезу екзополісахаридів на 1 г використаної глюкози за присутності іонів мангану в середовищі також знижувалася на 16\% (цитрат мангану) та на 36\% (сульфат мангану) порівняно 3 контрольним середовищем. На контрольному середовищі на 1 г використаної глюкози міцелій T. versicolor 353 продукував $114,5 \pm 8,3$ мг екзополісахаридів, на середовищі із сульфатом - 
$72,4 \pm 3,9$ мг, а на середовищі із цитратом 96,4 \pm 6,9 мг. Аналогічно до описаних результатів із цинком найвищий показник синтезу екзополісахаридів на 1 мг асимільованого азоту спостерігався за культивування T. versicolor 353 на контрольному середовищі. На контрольному живильному середовищі зі слідовою кількістю мангану $\left(5,1\right.$ мкг/дм $\left.{ }^{3}\right)$, на 1 мг асимільованого нітрогену, міцелій продукував $15,9 \pm 1,4$ мг екзополісахаридів, тоді як на середовищах із сульфатом мангану - тільки $9,1 \pm 0,7$ мг, а на середовищі із цитратом - 10,0 $\pm 0,6 \mathrm{мг.}$

Кількість синтезованих екзополісахаридів на 1 мкг акумульованих іонів мангану на середовищі із цитратом мангану (32,6 мг екзополісахаридів) була вищою порівняно із середовищем, яке містило сульфат мангану (19,7 мг екзополісахаридів).

Отримані дані свідчать, що сульфат мангану більше інгібує синтез екзополісахаридів, ніж цитрат мангану. Пригнічувальна дія цитрату мангану на синтез екзополісахаридів маскується загальним зростанням біомаси міцелію.

Додавання до середовища культивування міцелію іонів купруму негативно впливало на синтез екзополісахаридів. Ефективність синтезу екзополісахаридів на 1 г використаної глюкози зменшувалась на $33 \%$ на середовищі із сульфатом купруму $(77,0 \pm 6,2$ мг/г використаної глюкози) та на $73 \%$ на середовищі із цитратом купруму (30,8 $\pm 2,7$ мг/г використаної глюкози).

Як і у вищеописаних результатах, синтез екзополісахаридів на одиницю засвоєного нітрогену був найвищим на контрольному живильному середовищі. За відсутності купруму у живильному середовищі на 1 мг асимільованого нітрогену міцелій продукував $15,9 \pm 1,4$ мг екзополісахаридів, тоді як на середовищах із сульфатом купруму - на 54\% менше (7,3 $\pm 0,6$ мг/г нітрогену), а на середовищі із цитратом цей показник скорочувався на $82 \%(2,8 \pm$ 0,3 мг/г нітрогену). Ці дані свідчать, що існує зворотна залежність між накопиченням біомаси та акумуляцією іонів купруму, 3 одного боку, та синтезом полісахаридів - 3 іншого (рис. 2, 5). Таким чином, суттєве збільшення синтезу біомаси на середовищі з іонами купруму (особливо у цитратній формі) корелює зі скороченням синтезу екзополісахаридів.

Додавання до живильного середовища кожного 3 досліджених металів у формі цитрату чи сульфату викликало зміну співвідношення між синтезом екзополісахаридів і процесом асиміляції джерела азоту. У зв'язку з тим, що більша частина внутрішньоклітинного азоту входить до складу білків, можна зробити висновок про активізацію за дії досліджених металів внутрішньоклітинного метаболізму, що і відобразилося на даному співвідношенні.

Традиційно у працях із фізіології грибів використовують економічний коефіцієнт, який розраховують як співвідношення абсолютно сухої біомаси міцелію до кількості спожитої глюкози. Проте за такого розрахунку не враховують усю синтетичну активність гриба (синтезовані екстроцелюлярні сполуки, насамперед екзополісахариди). У нашому досліді на контрольному живильному середовищі кількість синтезованих екзополісахаридів становила майже $45 \%$ від маси міцелію. Вочевидь, на синтез такої маси екзополісахаридів витрачено значну частку енергії, яка не враховується за традиційних розрахунків економічного коефіцієнта. Спираючись на ці докази, ми ввели додаткове значення - загальний економічний коефіцієнт, який розраховується як співвідношення суми абсолютно сухої біомаси міцелію та маси екзополісахаридів до кількості спожитої глюкози (рис. 4). Уведення цього коефіцієнта дозволяє краще зрозуміти особливості впливу цитратів металів, синтезованих методом аквананотехнології, та відповідних сульфатів на фізіологію досліджуваного штаму.

Порівнюючи обидві форми економічних коефіцієнтів, а також враховуючи вищенаведений аналіз даних щодо синтезу екзополісахаридів, можна стверджувати, що серед досліджуваних цитратів i сульфатів лише цитрат цинку одночасно та позитивно впливає як на синтез біомаси, так і на синтез екзополісахаридів. Іони купруму сприяють «перемиканню» енергетичних і пластичних процесів у бік синтезу біомаси за рахунок зменшення синтезу екзополісахаридів. При цьому відбувається зростання енергетичних затрат на синтез цих полісахаридів, а енергетичні затрати на синтез біомаси зменшуються. Зазначимо, що за внесення у середовище іонів купруму у формі цитрату всі наведені явища були інтенсивнішими порівняно 3 дослідом, де у середовище вносили сульфат купруму в аналогічних (за вмістом катіона) концентраціях.

Особливу увагу слід звернути на різниці між впливом цитрату мангану та сульфатом цього елемента на пластичні та енергетичні показники синтезу біомаси та екзополісахаридів T. versicolor 353. Значення загального економічного коефіцієнта вказує на те, що внесення іонів мангану в концентрації 1 мг/дм ${ }^{3}$ у формі сульфату пригнічувало синтетичну активність $T$. versicolor 353, а аналогічна концентрація цього елемента, але внесена до середовища у формі цитрату мангану, в цілому позитивно впливала фізіологію цього штаму. При цьому також (як і з іонами купруму) відбувалось «перемикання» енергетичних і пластичних процесів у бік синтезу біомаси, а ефективність синтезу екзополісахаридів зменьшувалась.

\section{Висновки}

Більший вплив отриманих методом аквананотехнології цитратів мангану, цинку та купруму на зростання біомаси $T$. versicolor 353 пояснюється їх здатністю активувати системи, задіяні у процесах засвоєння джерел азоту та вуглецю. В усіх експериментальних серіях економічний коефіцієнт засвоєння глюкози та показники асиміляції нітрогену були вищими на $3-6 \%$ на середовищах із цитратами, ніж на середовищі з відповідними сульфатами. Найвищий економічний коефіцієнт синтезу біомаси (36\%) спостерігали на середовищі із цитратом купруму. Відповідно цитрат купруму найбільше серед досліджених металів збільшував рівень асиміляції джерела нітрогену до 35\% проти $18 \%$ на контрольному середовищі та на $29 \%$ на середовищі із сульфатом купруму.

Кількісний аналіз мікроелементів у біомасі T. versicolor 353 свідчить, що концентрація іонів купруму в міцелії, культивованому на середовищі із сульфатом купруму, становила 83,0 мкг/г, а на середовищі із цитратом купруму - 162,0 мкг/г біомаси. Кількісний аналіз іонів цинку та мангану у біомасі $T$. versicolor 353 не виявив статистично достовірної різниці між біодоступністю цитратної та сульфатної форми зазначених металів.

Значне зростання біомаси (на 79\% відносно контролю) за дії цитрату купруму, отриманого методом аквананотехнології, відбувається за рахунок зниження синтезу екзополісахаридів утричі порівняно $з$ контролем.

Серед використаних у дослідженні сполук лише цитрат цинку порівняно 3 контролем одночасно збільшував і синтез біомаси (на 37\%), і синтез екзополісахаридів (на 29\%).

\section{References}

Al-Maali, G. A. (2015). Vplyv cytrativ metaliv, otrymanyh metodom akvananotehnologii', na rist shtamiv likars'kyh makromicetiv Ganoderma lucidum 1900 i Trametes versicolor 353 [The influence of metal citrates obtained by aquananotechnology on growth of the strains of medical macromycetes Ganoderma lucidum 1900 and Trametes versicolor 353]. Ukrainian Botanical Journal, 72(4), 393-397 (in Ukrainian).

Al-Maali, G. A., Bisko, N. A., \& Ostapchuk, A. M. (2016a). Vplyv sul'fatu ta cytratu midi na sklad biomasy likars'kogo gryba Trametes versicolor (Polyporales, Polyporaceae) [The effect of citrate and sulfate of copper on the biomass composition of the medicinal mushroom Trametes versicolor (Polyporales, Polyporaceae)] Visnyk of Dnipropetrovsk University. Biology, Ecology, 24(1), 119-123 (in Ukrainian).

Al-Maali, G. A., Bisko, N. A., \& Ostapchuk, A. M. (2016b). Vplyv sul’fativ ta cytrativ metaliv na vuglevodnyj sklad biomasy likars'kogo gryba Trametes versicolor (Polyporales, Polyporaceae) [The effect of citrate and sulfate of different metals on carbohydrates composition of medicinal mushroom Trametes versicolor (Polyporales, Polyporaceae)]. Visnyk of Dnipropetrovsk University. Biology, Medicine, 7(1), 32-36 (in Ukrainian).

Aoyagi, H., Lino, Y., Takeo, T., Horii, Y., Morishita, Y., \& Horiuchi, R. (2009). Effects of OK-432 (Picibanil) on the estrogen receptors of mcf-7 cells and potentiation of antiproliferative effects of tamoxifen in combination with OK-432. Oncology, 54(5), 414-423.

Arteiro, J. M. S., Martins, M. R., Salvador, C., Candeias, M. F., Karmali, A., \& Caldeira, A. T. (2012). Protein-polysaccharides of Trametes versicolor: 
Production and biological activities. Medicinal Chemistry Research, 21(6), 937-943.

Banci, L. (Ed.). (2013). Metallomics and the cell. Metal Ions in Life Sciences. Springer, Netherlands.

Barros, A. B., Ferrão, J., \& Fernandes, T. (2016). A safety assessment of Coriolus versicolor biomass as a food supplement. Food and Nutrition Research, 60(1), 29953.

Bisko, N. A., Babyckaja, V. G., \& Buhalo, A. S. (2012). Byologycheskye svojstva lekarstvennyh makromycetov v kul'ture [Biological properties of medicinal macromycetes in culture] Alterpres, Kyiv (in Russian).

Bisko, N. A., Lomberg, M. L., Mytropolska, N. Y., \& Mykchaylova, O. B. (2016). The IBK Mushroom culture collection. Alterpres, Kyiv (in Ukrainian).

Borysevych, V. B., Kaplunenko, V. G., \& Kosinov, M. V. (2010). Nanomaterialy v biologii'. Osnovy nanoveterynarii' [Nanomaterials in biology. Fundamentals of nanotechnology]. Avicena, Kyiv (in Ukrainian).

Broadley, M. R., White, P. J., Hammond, J. P., Zelko, I., \& Lux, A. (2007). Zinc in plants. New Phytologist, 173(4), 677-702.

Chow, L. W. C., Lo, C. S. Y., Loo, W. T. Y., Hu, X., \& Sham, J. S. T. (2003). Polysaccharide peptide mediates apoptosis by up-regulating p21 gene and down-regulating cyclin D1 gene. The American Journal of Chinese Medicine, 31(1), 1-9.

Chu, K. K. W., Ho, S. S. S., \& Chow, A. H. L. (2002). Coriolus versicolor: A medicinal mushroom with promising immunotherapeutic values. Journal of Clinical Pharmacology, 42(9), 976-984.

Donatini, B. (2014). Control of oral human papillomavirus (HPV) by medicinal mushrooms, Trametes versicolor and Ganoderma lucidum: A preliminary clinical trial. International Journal of Medicinal Mushrooms, 16(5), 497-498.

Dudka, I. A., Vasser, S. P., \& Jellanskaja, I. A. (1982). Metody jeksperimental'noj mikologii [Methods of experimental mycology] Naukova Dumka, Kyiv (in Russian).

Elisashvili, V. I., Wasser, S. P., \& Kvesitadze, G. I. (2014). Physiology of biologically active metabolite production by medicinal mushrooms. Annals of Agrarian Science, 10(2), 63-67.

Fujita, H., Ogawa, K., Ikuzawa, M., Muto, S., Matsuki, M., Nakajima, S., Shimamura, M., Togawa, M., Yoshikumi, C., \& Kawai, Y. (1988). Effect of PSK, a protein-bound polysaccharide from Coriolus versicolor, on drugmetabolizing enzymes in sarcoma-180 bearing and normal mice. International Journal of Immunopharmacology, 10(4), 445-450.

Hirose, K., Hakozaki, M., Kakuchi, J., Matsunaga, K., Yoshikumi, C., Takahashi, M., Tochikura, T. S., \& Yamamoto, N. (1987). A biological response modifier, PSK, inhibits reverse transcriptase in vitro. Biochemical and Biophysical Research Communications, 149(2), 562-567.

Hobbs, C. (2005). Medicinal value of turkey tail fungus Trametes versicolor (L.: Fr.) Pilat (Aphyllophoromycetideae). International Journal of Medicinal Mushrooms, 7(3), 346-347.

Kaim, W., Schwederski, B., \& Klein, A. (2013). Bioinorganic chemistry: Inorganic elements in the chemistry of life: An introduction and guide. John Wiley \& Sons.

Kao, C., Jesuthasan, A. C., Bishop, K. S., Glucina, M. P., \& Ferguson, L. R. (2013). Anti-cancer activities of Ganoderma lucidum: Active ingredients and pathways. Functional Foods in Health and Disease, 3(2), 48-65.

Klechak, I. R., Bis'ko, N. A., Mytropol's'ka, N. J., Antonenko, L. O. (2013). Vplyv cytrativ biogennyh metaliv, otrymanyh metodom akvananotehnologij, na rist i biosyntetychnu aktyvnist' likars'kogo gryba Trametes versicolor [Influence of citruses of biogenic metals, obtained by the method of aquanotechnology, on growth and biosynthetic activity of medicinal fungus Trametes versicolor]. Research Bulletin of NTUU Kyiv Polytechnic Institute, 3, 59-64 (in Ukrainian).
Latimer, G. W. (2012). Official methods of analysis of AOAC International. AOAC international.

Law, N. A., Caudle, M. T., \& Pecoraro, V. L. (1998). Manganese redox enzymes and model systems: Properties, structures, and reactivity. Advances in Inorganic Chemistry, 305-440.

Leliebre-Lara, V., Monzote Fidalgo, L., Pferschy-Wenzig, E.-M., Kunert, O., Nogueiras Lima, C., \& Bauer, R. (2016). In vitro antileishmanial activity of sterols from Trametes versicolor (Bres. Rivarden). Molecules, 21(8), 1045.

Mizuno, T. (1999). The extraction and development of antitumor-active polysaccharides from medicinal mushrooms in japan (review). Intemational Journal of Medicinal Mushrooms, 1(1), 9-29.

Monma, Y., Kawana, T., \& Shimizu, F. (1997). In vitro inactivation of herpes simplex virus by a biological response modifier, PSK. Antiviral Research, 35(3), 131-138.

Monro, J. A. (2003). Treatment of cancer with mushroom products. Archives of Environmental Health, 58(8), 533-537.

Ohmura, Y., Matsunaga, K., Motokawa, I., Sakurai, K., \& Ando, T. (2003). Protective effects of a protein-bound polysaccharide, PSK, against Candida albicans infection in syngeneic tumor-bearing micevia Th1 cell functions. Cancer Biotherapy and Radiopharmaceuticals, 18(5), 769-780.

Ohmura, Y., Matsunaga, K., Motokawa, I., Sakurai, K., \& Ando, T. (2001). Protective effects of a protein-bound polysaccharide, PSK, on Candida albicans infection in mice via tumor necrosis factor- $\alpha$ induction. International Immunopharmacology, 1(9-10), 1797-1811.

Pert, S. J. (1978). Osnovy kul'tivirovanija mikroorganizmov i kletok. [Fundamentals of cultivation of microorganisms and cells]. Nauka, Moscow (in Russian).

Rowan, N. J., Smith, J. E., \& Sullivan, R. (2003). Immunomodulatory activities of mushroom glucans and polysaccharide-protein complexes in animals and humans (A review). International Journal of Medicinal Mushrooms, 5(2), 95-110.

Staats, C. C., Kmetzsch, L., Schrank, A., \& Vainstein, M. H. (2013). Fungal zinc metabolism and its connections to virulence. Frontiers in Cellular and Infection Microbiology, 3, 65.

Standish, L. J., Wenner, C. A., Sweet, E. S., Bridge, C., Nelson, A., Martzen, M., Novack, J., \& Torkelson, C. (2008). Trametes versicolor mushroom immune therapy in breast cancer. Journal of the Society for Integrative Oncology, 6(3), 122-128.

Titova, L. O., \& Klechak, I. R. (2015). Osoblyvosti kul'tyvuvannja vyshhogo bazydial'nogo gryba Trametes zonatus na ridkyh seredovyshhah. [Features of cultivation of higher basidial fungus Trametes zonatus on liquid medium]. Naukovi Visti Nacional'nogo Tehnichnogo Universytetu Ukrai'ny Kyi'vs'kyj Politehnichnyj Instytut, 3, 76-83 (in Ukrainian).

Torkelson, C. J., Sweet, E., Martzen, M. R., Sasagawa, M., Wenner, C. A., Gay, J., Putiri, A., \& Standish, L. J. (2012). Phase 1 clinical trial of Trametes versicolor in women with breast cancer. ISRN Oncology, 251632.

Tsukagoshi, S. (1984). Krestin (PSK). Cancer Treatment Reviews, 11(2), 131155.

Wenner, C., Inatsuka, C., Davis Smith, T., Sasagawa, M., Martzen, M., Standish, L., Dasis, M., \& Lu, H. (2013). Anti-tumor actions of Trametes versicolor extract polysaccharide $\mathrm{K}$ include activation of dendritic cells and gamma delta T cells. Planta Medica, 79(10)

Yeung, J. H. K., Chiu, L. C. M., \& Ooi, V. E. C. (1995). Effect of polysaccharide peptide (PSP) on in vivo sulphation and glucuronidation of paracetamol in the rat. European Journal of Drug Metabolism and Pharmacokinetics, 20(4), 287-292.

Ying, J., Mao, X., Ma, Q., Zong, Y., \& Wen, H. (1987). Icons of medicinal fungi from China (translated, Yuehan X). Science Press, Beijing. 